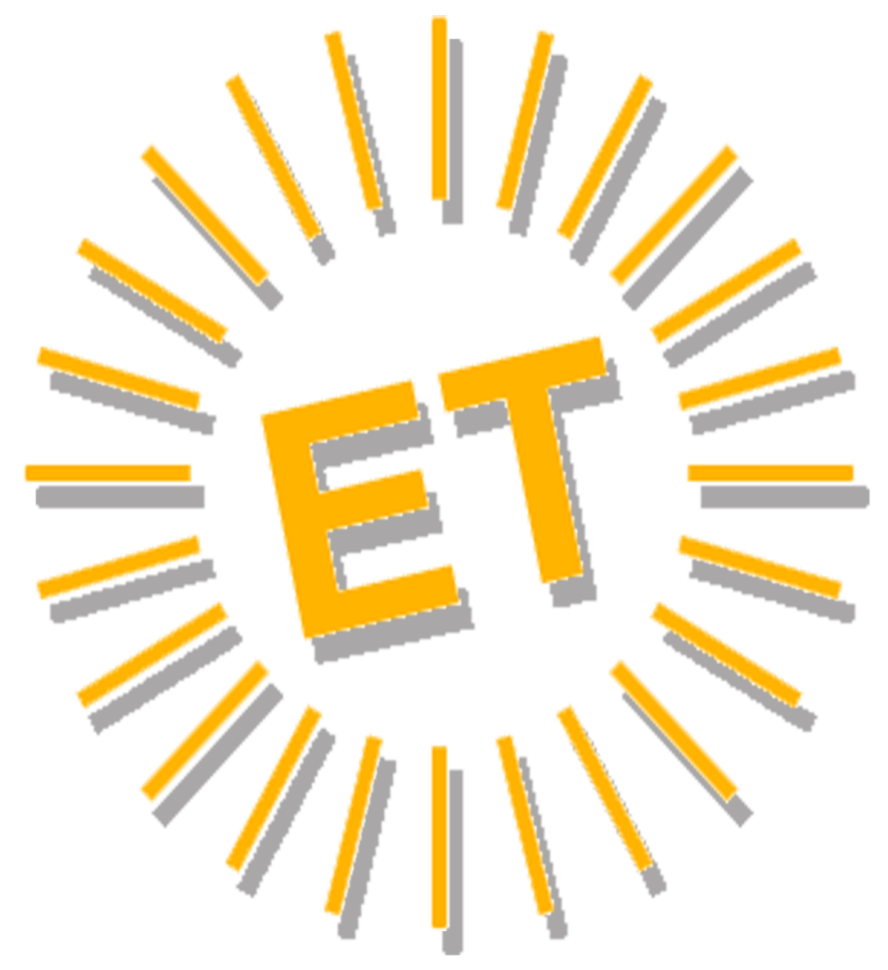




\section{Editorial Team}

\section{Editor in Chief}

Alfonso Vargas-Sánchez, University of Huelva, Spain

\section{Associate Editor}

Mirko Perano, Reald University College, Albania

\section{Books Review Editor}

Brendan Paddison, York St. John University, United Kingdom

\section{Secretariat}

Elena García de Soto, University of Huelva, Spain

Cinta Borrero-Domínguez, University of Seville, Spain

\section{Style reviewer and text editor}

Anestis Fotiadis, Zayed University, United Arab Emirates

\section{Editorial Board}

José Manuel Alcaraz, Murdoch University, Australia Mario Castellanos-Verdugo, University of Seville, Spain José Antonio Fraiz-Brea, University of Vigo, Spain José Manuel Hernández-Mogollón, University of Extremadura, Spain

Tzung-Chen Huan, National Chiayi University, Taiwan, Province of China

Shaul Krakover, Ben Gurion University, Israel Jean Pierre Levy-Mangin, University of Quebec, Canada Tomás López-Guzmán, University of Córdoba, Spain Yasuo Ohe, Chiba University, Japón

María de los Ángeles Plaza-Mejía, University of Huelva, Spain Nuria Porras-Bueno, University of Huelva, Spain João Albino Silva, Algarve University, Portugal

\section{Advisory Board (Spanish Members)}

Juan Manuel Berbel-Pineda, Pablo de Olavide University, Spain César Camisón-Zornoza, Uniersity of Valencia, Spain Enrique Claver-Cortés, University of Alicante, Spain María Teresa Fernández-Alles, University of Cádiz, Spain José Luis Galán-González, University of Seville, Spain Félix Grande-Torraleja, University of Jaén, Spain

Antonio Leal-Millán, University of Seville, Spain Inmaculada Martín-Rojo, University of Málaga, Spain Antonio Manuel Martínez-López, University of Huelva, Spain Francisco José Martínez-López, University of Huelva, Spain Pablo A. Muñoz-Gallego, University of Salamanca, Spain
Francisco Riquel-Ligero, University of Huelva, Spain José Miguel Rodríguez-Antón, Autonomous University of Madrid, Spain

Sandra Sanchez-Cañizares, University of Cordoba, Spain Josep Francesc Valls-Giménez, ESADE, Spain

\section{Advisory Board (Other European Members)}

Tindara Abbate, University of Messina, Italy Paulo Aguas, University of Algarve, Portugal Carlos Costa, Aveiro University, Portugal Dianne Dredge, Aalborg University, Denmark Salvatore Esposito de Falco, University of Rome "La Sapienza", Italy

Sheila Flanagan, Dublín Institute of Technology, Ireland Tania Gorcheva, Tsenov Academy of Economics, Bulgaria Tadeja Jere Jakulin, University of Primorska, Slovenia Metin Kozak, Mugla University, Turkey Álvaro Matias, Lusiada University, Portugal Alfonso Morvillo, National Research Council, Italy Alexandru Nedelea, Stefan cel Mare University of Suceava, Romania Claudio Nigro, University of Foggia, Italy Angelo Presenza, University "G. D'Annunzio" of Chieti-Pescara, Italy

Kanes Rajah, Royal Agricultural University, United Kingdom

\section{Advisory Board (Members from the rest of the world)}

John Allee, American University of Sharjah, United Arab Emirates

Nestor Pedro Braidot, National University of La Plata, Argentina

Roberto Elias Canese, Columbia University, Rector, Paraguay

Luca Casali, Queensland University of Technology, Australia Nimit Chowdhary, Indian Institute of Tourism and Travel Management, India

Steven Chung-chi Wu, National Pingtung University of Science and Technology, Taiwán

Dianne Dredge, Southern Cross University, Australia Daniel Fesenmaier, Temple University, United States

Babu George, Alaska Pacific University, United States Dogan Gursoy, Washington State University, United States Jafar Jafari, University of Wisconsin-Stout, United States Sanggun Lee, Pai Chai University, Korea Republic of Albert Yeh Shangpao, I-SHOU University, Taiwán Pauline Sheldon, University of Hawaii, United States Germán A. Sierra-Anaya, University of Cartagena de Indias, Rector, Colombia Xiaohua Yang, University of San Francisco, United States 


\title{
TOURISM AMBASSADORS AS SPECIAL DESTINATION IMAGE INDUCERS
}

\author{
Jean Claude Morand \\ International Federation for IT in Tourism \& Travel (France) \\ jean-claude.morand@ifitt.org
}

Lucília Cardoso

CITUR (Portugal)

lucyalves.lucilia@gmail.com

Alexandra Matos Pereira

ISLA-Instituto Politécnico de Gestão e Tecnologia (Portugal)

alexandra.pereira@islagaia.pt

\author{
Noelia Araújo Vila \\ University of Vigo (Spain) \\ naraujo@uvigo.es
}

Giovana Goretti Feijó de Almeida

CITUR (Portugal)

goretti.giovana@gmail.com 
ABSTRACT

The image of destinations is a key factor when it comes to positioning and attracting the attention and interest of potential tourists. That being, the subject matter is relevant to experts and academics as well as destination managers looking for new alternatives to generate greater impact and influence. Today, the use of information and communication technologies (ICT) is widespread in all areas of life, being also useful and fully adopted in tourism image projections, mainly through social networks. Accordingly, this article focuses on the figure of the tourism ambassador as a diffuser or enhancer of the image of a tourism destination, particularly through the use of an appropriate web platform created by the French tourism destination authority-the Ambassadeurs Savoie Mont Blanc. To understand the repercussions of this initiative, a content analysis of its official Facebook page is made, studying variables such as fans, content and engagement.

KEYWORDS

Destination brand image; Tourism ambassadors; Destination imagery; Brand awareness; Ambassadeurs Savoie Mont Blanc.

ECONLIT KEYS

L83; Z33; $M 30$

\section{INTRODUCTION}

For several decades, the research topics "destination brand image" and "destination image" have remained as two independent domains and have historically been considered as independent lines of research (Boo et al., 2009; Konecnik \& Gartner, 2007; Pike, 2009). Tourism researchers have been studying the image of destinations, while marketing researchers have been dedicated to studying the brand. At the turn of the century, with the advent of territorial branding, branding concepts and techniques were transposed to the tourism phenomenon under the guidance of marketing experts. However, there has been a gradual integration of these two concepts. From the marketing researchers' perspective, the notion of destination image needs to be included in the definition of destination branding (Blain et al., 2005). As for tourism researchers, they agree with the common-sense judgment expressed by Konecnik and Gartner (2007), according to which image cannot be considered as the only explanatory factor of the decision-making process in tourism, given that it is necessary to isolate it from important dimensions such as notoriety, quality and loyalty. 
Crompton's definition of brand image or destination image being a single sum of beliefs, ideas and impressions/perceptions that one person has about a destination/place (Beerli \& Martín, 2004; Crompton, 1979; Hallmann et al., 2015) serves both parties. Through branding, destinations build their reputation and differentiate themselves from competitors to reach customers and create loyalty among their target markets (Pike \& Page, 2014).

The literature has demonstrated the central role of partnerships (Hankinson, 2012) and collaboration (Scott et al., 2008) in destination branding, but empirical studies on the role of tourism ambassadors in destination and place branding are still rare. Therefore, this study attempts to fill this research gap by aiming to increase the understanding of destination brand image development dynamics from a tourism ambassador perspective. In particular, it will focus on county ambassadors promoting Savoie Mont Blanc as a destination for investment, tourism, learning and living, as their commitment and support are crucial for the destination brand to succeed (Gartner \& Ruzzier, 2011; Hankinson, 2004).

This research examines the Savoie Mont Blanc Ambassadeurs' Facebook page to determine their actual online behaviour, behavioural intentions and role differences to create a classification chart. As a result, it will allow their different roles as online place ambassadors - that is to say, individuals who positively endorse and promote a place to visitors and other stakeholders, via online platforms or social media-to be identified, determined and classified. As an exploratory study, this approach to this underknown phenomenon allows its degree of familiarity to increase and contributes to determining the best approach to future research. Besides, it may constitute an end in itself (Babbie \& Huitt, 1979).

Given the impact these multiple actors and factors have on the brand image development process, this study's findings provide evidence of the co-existence of multiple users posting bulk data, which may be considered a promising aspect of digital media marketing, mainly the most active ambassadors' Facebook pages, and this may pave the way for further studies.

\section{THEORETICAL BACKGROUND}


According to Cai (2002, p. 723), "destination brand image is a set of perceptions concerning a place that translates the existing associations in the tourist's memory". Keller (1993) has argued that the construction of the brand destination image consists, essentially, in identifying the most relevant associations of the destination and in strengthening emotional bonds with the brand. In this framework, Ekinci (2003) proposed a conceptual model of destination branding, reflecting these ideas and advocating that destination image is composed of three elements: global image, destination brand and, derived from this last, brand personality. Moreover, Qu et al. (2011) maintained that a destination's overall image (in other words, its brand image) mediates the relationship between its brand associations and tourists' future behaviour. A further approach has been provided by Konecnik and Gartner (2007), who built on Keller's $(1993 ; 2008 ; 2016)$ work to propose the concept of customerbased brand equity for tourism destinations (CBBE-TD), which consists of four interrelated components: (1) destination brand awareness expresses how highlighted a destination brand name is in the tourist's mind (Aaker, 1996), (2) destination image is the sum of associations a tourist has with a given destination, (3) perceived quality consists of customers' overall perception regarding the quality of products or services in comparison to the competition (Aaker, 1996) and (4) destination loyalty reflects a tourist's attachment to the destination brand.

Still, in the context of destination brand equity, García et al. (2012) proposed a conceptual model for the relationship between destination image and destination brand to analyse a destination brand's success. This model proposes five variables to analyse destination image: (1) infrastructure and socioeconomic environment, (2) natural and cultural resources, (3) pleasant atmosphere, (4) social setting environment and (5) overall image. The model also proposes four variables to decompound destination brand: presented brand, brand awareness, brand meaning and brand equity (p. 650). More recently, Dias and Cardoso (2018) presented the destination brand choice (DBC) model, which added a fifth stage to the Aaker model (1996), called the post-visit re-evaluation, recognising the fact that the quality of a tourist's experience may influence future travel decisions. This means that a tourist also perceives destination image based on the tourism experiences that may occur at the destination (Boo et al., 2009). 
Returning to Keller's definition, brand image is the set of memory-based associations related to how consumers perceive a brand (Keller, 1993). In a destination image context (considering mainly tourists' perceptions), according to the CBBE-TD model, destination brand awareness (the first stage of brand equity) expresses how highlighted a destination brand name is in a tourist's mind (Aaker, 1996). Therefore, and taking into account that destination image occupies the second stage of destination brand equity (Konecnik \& Gartner 2007), the question that can be posed is the following: how is a destination image built in a tourist's memory?

\section{1) ABOUT DESTINATION BRAND IMAGE CONSTRUCTION}

According to Gartner (1993), awareness implies that a given destination image exists in the mind of potential tourists, and if a destination wants to be successful, it must achieve firstly awareness and then a positive image. In other words, if the name of the destination is evoked by the tourist, it means that the tourist somehow knows that destination brand. This builds on Keller's (1993) argument that brand image is the set of memory-based associations that consumers have with a brand. The image perception process models can help us to understand the preceding factors that influence the image formation process and answer the aforementioned question. For tourism marketing experts (Echtner \& Ritchie, 2003; Gallarza et al., 2002; Hosany et al., 2007; Konecnik, 2005), destination image represents an overall impression of the destination or, to be more precise, a set of impressions and feelings about it. Some authors (Baloglu \& Mangaloglu, 2001; Gallarza et al., 2002; Gartner, 1994; Gunn, 1972; Konecnik, 2005) have identified two types of tourist destination images: organic and induced (Cardoso et al., 2018). An organic image is created from noncommercial sources and is formed by the cultural component, that is, by general knowledge and by friends' information. An induced image differs from the organic one since it is formed when the tourist seeks voluntarily or is submitted to any available commercial sources of information that stakeholders promote through the most diverse means (Cardoso et al., 2018; Gallarza et al., 2002; Önder \& Marchiori, 2017). 
The most complete model of destination image formation is the Gartner model (1994), which proposes that the image formation process is a continuum from overinduced to autonomous and organic agents. It defines "image forming agent" as "a force that produces a specific result" (Gartner, 1994, p.197) in the destination image. Each agent has its characteristics, so image formation differs according to the type of agent involved. Thus, as claimed by Gartner (1994), this process of image formation involves eight agents: (1) overt induced I-traditional forms of advertising; (2) overt induced II-tour operator and tourism organisations' advertising. In this case, the real image and the projected image may not coincide because the main interest of tour operators is to create attractive images for tourism destinations where they already have elaborate packages; (3) covert induced I-when celebrities are used to promote a tourism destination. Well-known people are used to draw attention and bring more credibility to the tourism destination. An example is the 2014 "Home from Home: Celebrities at TIFF Talk Toronto" campaign. In the promotional video, it is possible to identify several celebrities talking about the attributes of the destination; (4) covert induced II-appeal to writers, filmmakers, reporters, etc., who produce reports or films about a tourism destination, which seem impartial, but they are not; (5) autonomous-independent professionals, including news, documentaries, films, and TV show broadcasters, songwriters, bloggers, filmmakers, etc. These agents are destination image ambassadors so much so that this category presents two subcategories: news and popular culture. Generally, tour destination promoters do not control the information, as the projected image is the reporter's responsibility; (6) unsolicited organic-recommendations/word of mouth from friends who have been in the destination or have feelings and opinions about it. In the current digital context, the visual appeal of images is what prevails, and the social networks are an excellent example of this image-forming agent; (7) solicited organic-information that the tourist has searched for about a destination; and (8) organic-the last stage of the process of image formation that is built based on the visit to the destination.

Only the autonomous agent has a significant impact on the tourist because people are likely to consider information as relatively unbiased when compared to traditional advertising (Kim \& Richardson, 2003). Baloglu and McCleary (1999) have argued that the destination image created by stimulus factors depends on the 
quantity and type of information. So, in the process of destination image formation, there are two different types of destination image: the induced image created by external stimuli and the organic image formed by the tourist experience at the destination (Baloglu \& Mangaloglu, 2001; Gartner, 1994; Konecnik, 2005; Prebensen, 2007). Moreover, the formation of destination image reveals its dynamic character, as destination image is not static and is built over time-an important and useful viewpoint for the branding of tourism destinations, as each image is a manageable instrument (Beerli \& Martín 2004). The way the destination image is evoked in the tourist's memory is explained by the destination imagery process (DYP) model of Cardoso et al. (2019). The authors have argued that studying induced destination images is understanding destination imagery, which can be defined as "momentary processes of storage and retrieval of information from memory upon receiving destination stimuli and resulting in holistic perceptions of a destination" (Cardoso et al., 2019, p. 85). The result of this destination image recalling process in the tourist's memory, or more accurately the destination imagery, are the perceptions of the destination's attributes (Cardoso et al., 2019). The study of Battour et al. (2011) supports that destination image attributes have a strong impact on destination choice. Besides, there are other studies that have shown the impact of ambassadors' content analysis on the web through the analysis of tweets in the case of Tweeter or likes when talking about Facebook (Anderson, 2006; Serna et al., 2014; Yoganathan et al., 2019).

In 2009, Andersson and Ekman (2009) presented the concept of brand ambassadors as a recent phenomenon, even in the business world. Nowadays, this concept is not perceived as new, and it is often cloaked in other terminologies, such as co-creation, linked to the web content of photographers (Kim \& Stepchenkova, 2015) and others. Brand ambassadors are also co-creators of brand image because they can publish information about a destination that will influence other users' perceptions (Jabreel et al., 2017). The photography of a destination, besides its aesthetic character, tells a story and narrates a place. It is a storytelling narrative organically constructed from the photographer's lens that conveys visual perceptions and strengthens the destination brand identity (Camprubí \& Planas, 2020). 
Destination image formation (e.g. the photographs) incorporates sources of information that include a socio-cultural dimension (Kislali et al., 2019). Thus, it is almost impossible to strengthen or create a destination image without also acknowledging the local culture (Woosnam et al., 2020). The destination image made possible through social networks builds and reconstructs the knowledge about a destination (Pan et al., 2021). This image construction is possible by assembling different perspectives resulting from the symbolic-cultural system of the community and the influence of the destination image disseminated by marketing (Pretto, 2021). Thus, this analysis focuses on how destination image is influenced and by which means destination attributes and experiences are conveyed to affect the image of a destination.

As shown in Figure 1, and considering the previous theoretical exposition, five factors are considered to be inducers of the destination image formation: (1) the tourist's memory; (2) traditional promotion within destination brand; (3) previsit perceptions, post-visit evaluations and destination ambassadors.

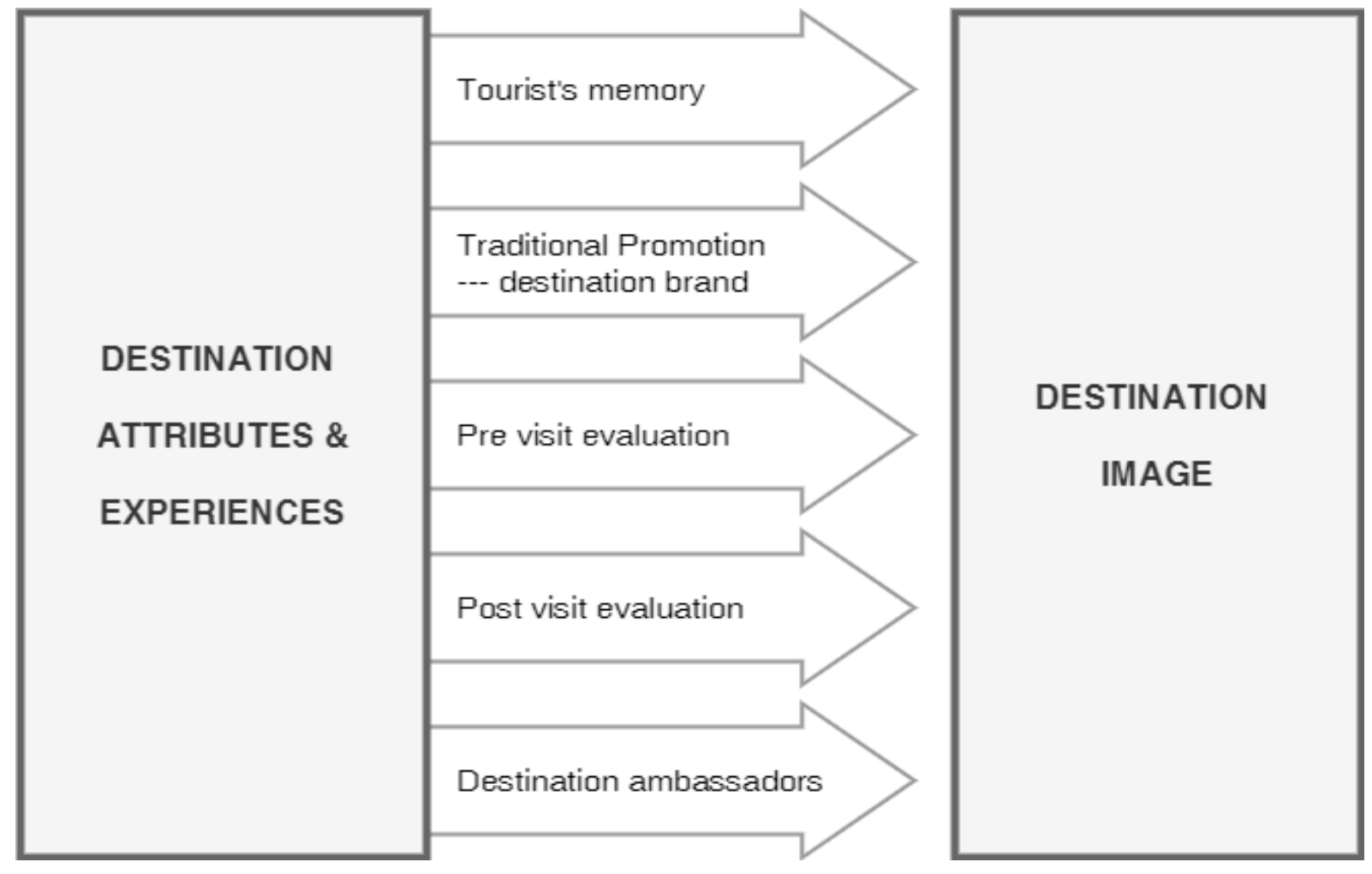

Figure1. Inducer factors of destination image formation. Source: Authors (2021) with base in the literature review. 
Personal characteristics influence the cognitive image of destinations, and the experience gained from previous visits is also important, but nowadays information obtained from outside sources, mainly social networks, may be more important. The destination image perceived in the mind of the tourist is mediated by a person's identity, cultural background and social, personal and psychological characteristics (Govers \& Go, 2005), which explains the significant power of the influence of tourism ambassadors.

Using Australia as an example (A Different Light Campaign, 2004), Glover's article (2009) examined the potential influences of celebrity endorsement on destination image through the application of Gallarza et al.'s (2002) framework of image characteristics. Findings suggest that celebrities may affect many aspects of destination image, namely, complexity, multiplicity, relativity and dynamics, but it also highlighted that there are many more aspects that warrant further attention.

Diesbach (2012, p. 229) stated that "the concepts of brand ambassador and destination ambassador are often understood in a very limited approach with confusion, and not much effect, because they only rely on strike power, famousness". This limitation is often linked to the fact that celebrities are invited by campaign managers to support destinations' promotional campaigns, and because of that, the information is somewhat manipulated. However, some celebrities are spontaneous ambassadors like Lionel Messi (the football player), who was appointed as the Ambassador of Responsible Tourism by the World Tourism Organisation in 2018 (http://media.unwto.org/press-release/2018-02-07/fernando-hierro-new-unwtoambassador-responsible-tourism) or Cristiano Ronaldo, considered the best ambassador of Funchal (Portugal), his homeland. In this paper, a brand ambassador is conceptualised as a "credible testimony of the distinctive character of the place and its attractiveness and can through the word-of-mouth effect influence others through their networks and relationships" (Andersson \& Ekman, 2009, p. 43).

The literature makes a clear distinction between the macro- (celebrity) endorser and the micro-influencer. Macro-celebrities are reference people who attract the public. They are considered influential, as they can exert an influence on consumers' buying attitudes and can trigger behavioural changes (Chung \& Cho, 2017). The 
credibility of the source depends on three factors: expertise, reliability and friendliness. Expertise evidences the communicator's ability to support that content that is transmitted through advertising. Reliability is related to the communicator's objectivity and honesty, and friendliness describes the attractiveness of the source (Vaghela, 2012).

The influence a person can have on social media networks has been studied by Cha et al. (2010), who introduced three different types of influence in their case study of Twitter. First of all, a person may have indegree influence, which is the number of followers or, in other words, the size of a user's audience. Secondly, a person may gain retweet influence, which indicates the ability to generate content which spreads across the user's audience. Thirdly, mention influence measures the number of mentions containing a user's name and indicates whether a user can engage others in a conversation.

Several studies have concluded that celebrity endorsements influence consumers' buying decisions (Bergkvist \& Zhou, 2016; McCracken, 1989). The argument is that the endorsement process depends upon the symbolic properties of the celebrity endorser. Using a "meaning transfer" perspective, these properties are shown to reside in the celebrity and to move from celebrity to consumer good and from good to consumer. As McCracken (1989) has defined it, a celebrity endorser is any individual who enjoys public recognition and who uses this recognition on behalf of a consumer good by appearing with it in an advertisement.

Those studies stress that online users recall those products that are promoted by celebrity endorsers. The credible endorsers can influence their followers' perceptions about the quality of the brands' products, as they may associate the endorsed products with the image of the celebrities (Hollensen \& Schimmelpfennig, 2013). For this reason, they are increasingly being employed by businesses as their endorsements are perceived as credible and trustworthy by their followers. Hence, they contribute to raise awareness about the brands' destinations and services. In a similar vein, Bergkvist et al. (2016) reported that celebrity endorsements have an impact on consumers' buying decisions, particularly when they realise that the celebrities are not motivated by the money they receive but by the quality of the 
products/destinations that they endorse, as in the case of tourism ambassadors who work pro bono.

Defining the concept of tourism ambassadors and situating it in the context of this study might be complex and localised, as there is no agreed upon working definition among scholars regarding this subject (Majid, 2019). It is well acknowledged that tourism destination brand ambassadors authenticate the validity of features which distinguish destinations and give them attractiveness and that this can affect other networks and relationships by word-of-mouth effects. Due to the figurative sense that the phrase could convey, as Majid (2019) claims, a tourism destination brand ambassador is "anyone likely to promote the touristic potentials treasured in a certain area" (2019, p. 318).

At an international level, the conceptions found are indeed diverse. Uchinaka et al. (2019) have considered residents as place ambassadors. Other studies have highlighted the role of restaurants as cultural ambassadors (Min \& Lee, 2014; Wood \& Muñoz, 2007) or food ambassadors (Alonso \& Krajsic, 2013). In line with the notion reviewed in this paper, the main tasks of Eisenstrasse ambassadors from rural areas in Austria (due to their personal relation to the region) is either to publicise, facilitate and enhance the framework conditions of the region in all fields-economy, culture, tourism, education and media-due to their personal relation to the region (Harfst et al., 2017) or to act as citizen brand ambassadors with actual participation in the 'be Berlin' branding campaign (Rehmet \& Dinnie, 2013).

For the empirical part of this study, the focus is then to take a look at the performance of these tourism ambassadors through the social media of their associations and investigate how they carry out the duty imposed on them.

\section{2) THEORETICAL APPROACH OF A DESTINATION MANAGEMENT ORGANISATION AMBASSADOR MODEL}

Taking into consideration the long-tail model elaborated by Anderson (2006), this study's core approach is the democratic production of the destination content, the socalled user-generated content (UGC) consisting of any content-text, videos, images, reviews, etc.-created by people rather than destinations. 
Several studies (Serna et al., 2014; Yoganathan et al., 2019) have analysed the impact of the content analysis of ambassadors on the web through examining the number of tweets in case of Twitter or likes when talking about Facebook.

There is a growing discussion about constitutes a large number of followers/likes or acceptable levels of followers/likes to be classified as a social media influencer. De Veirman et al. (2017) classified a low level of following as 2100 followers and 21,000 as a high number of followers, whereas other studies have made the distinction between a macro- or micro-influencer based upon the average number of likes their posts attracted. Xiong et al. (2018) argued that there is no consistent measurement regarding perceived opinion leader status. This leaves little consensus regarding the level of followers that allows social media influencers to be segmented into distinct groups.

In fact, the number of likes from Facebook posts may not correspond to the promotion of a destination, or the content of comments may give an undesired meaning when it comes to the destination image via social media. To overcome this flaw, the Savoie Mont Blanc Ambassadeurs' community is a trusted group relaying posts corresponding to the promotion of the destination, reinforced by the fact that only the communication between the destination management organisation (DMO) and the selected ambassadors is being considered.

The methodology used here to test the hypotheses considers the number of interactions generated by the following three subgroups of ambassadors per week, assuming that three posts are published each week (Figure 2): (1) a small number of personalities followed by a substantial number of people, (2) tourism professionals using the social networks and (3) citizens willing to act as ambassadors and communicate on social networks. 


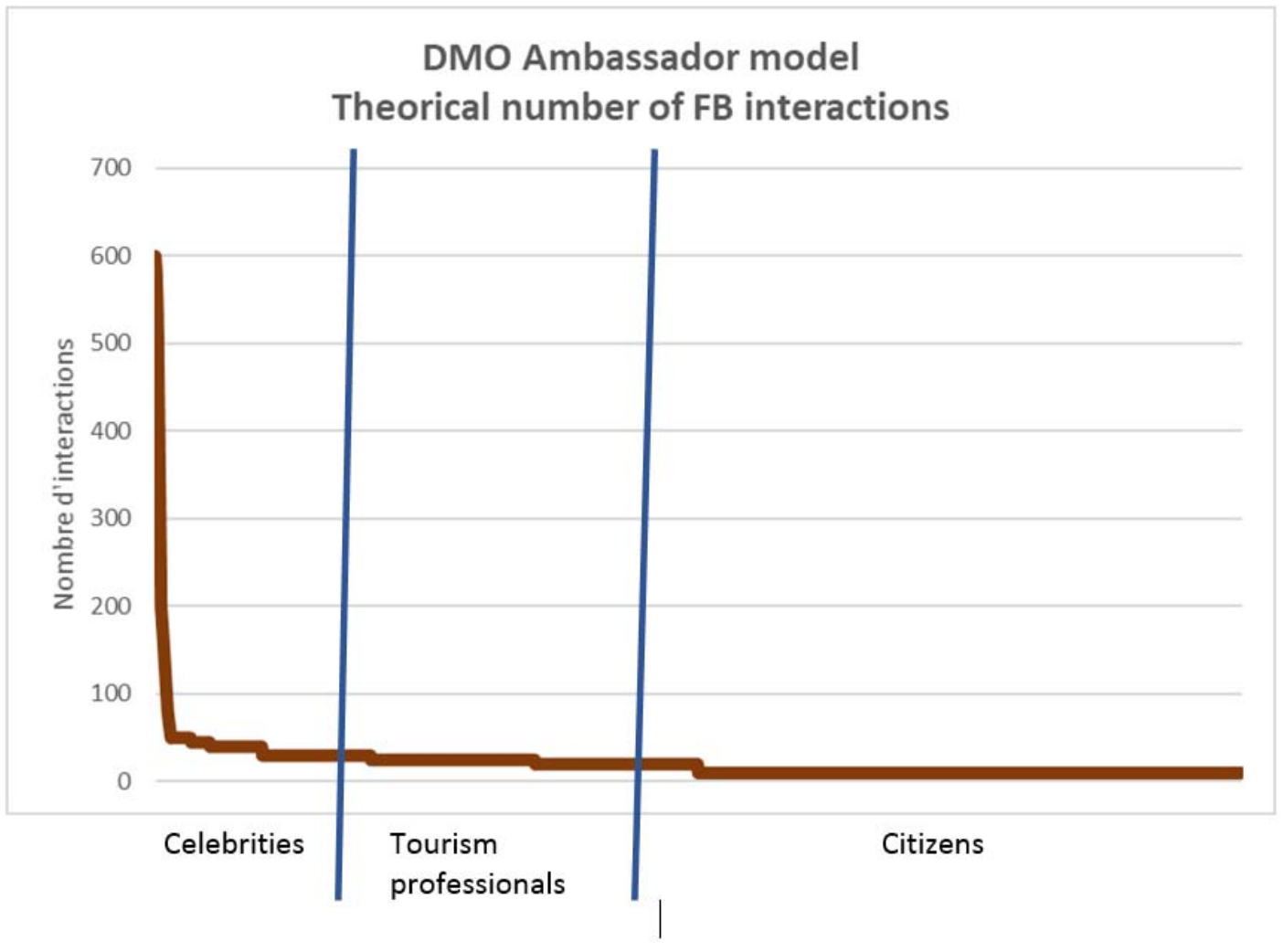

Figure 2. DMO Ambassador model - Theoretical number of Facebook interactions. Source: Adapted from Anderson (2006).

To draft this long tail diagram, the following work hypotheses (Table 1) have been considered:

\begin{tabular}{|c|c|c|c|c|}
\hline Sub-group & $\begin{array}{c}\text { Estimated } \\
\text { number of } \\
\text { persons }\end{array}$ & $\begin{array}{c}\text { Number of } \\
\text { interaction's } \\
\text { range }\end{array}$ & $\begin{array}{c}\text { Estimated number } \\
\text { of FB interactions } \\
\text { per week }\end{array}$ & $\begin{array}{c}\text { Percentage } \\
\text { of } \\
\text { interactions }\end{array}$ \\
\hline Celebrities & 10 & 350 to 600 & 4570 & $10.37 \%$ \\
\hline $\begin{array}{c}\text { Tourism } \\
\text { Professionals }\end{array}$ & 390 & 25 to 300 & 16010 & $36.32 \%$ \\
\hline Citizens & 1600 & 10 to 25 & 23500 & $53.31 \%$ \\
\hline Total & 2000 & & 44080 & \\
\hline
\end{tabular}

Table 1. The hypothesis of the number of interactions that can be generated by a network of DMO ambassadors. Source: Based on Anderson (2006).

To validate these hypotheses, publicly available data from Savoie Mont-Blanc Tourism was used, assuming only the number of interactions generated by Facebook 
posts. The sample was limited to 2000 individuals, assuming that only $40 \%$ of the ambassadors would post on Facebook.

Providing these assumptions are correct, the extension of the DMO ambassador model would generate nearly $90 \%$ of the interactions with the Facebook population. These interactions being a supplement to the interactions generated by the celebrities.

\section{CASE STUDY: "AMBASSADEURS SAVOIE MONT BLANC"}

"Savoie Mont Blanc Tourisme" is the DMO in charge of promoting tourism for the Savoie and Haute-Savoie areas, a region registering more than 66 million tourist nights and which generates nearly 49,000 jobs. This is a four-season destination mainly oriented to winter sports and the mountaineering but also including a substantial offer in terms of Meeting, Incentive, Congress and Events (MICE) and thermal spots. A network of local tourism offices exists to promote well-known destinations such as Tignes, Val d'Isère, Chamonix and Annecy. All communication channels are used to reach potential tourists, including a panel of online tools from websites, Customer Relationship Management (CRM) and social networks.

For many years, a large number of personalities like Cezanne the painter or Jean-Jacques Rousseau or Lamartine were used to promote the destination outside of a formal marketing approach. Since the beginning of the $20^{\text {th }}$ century, famous skiers such as Jean-Claude Killy or mountaineers as Maurice Herzog have also acted as ambassadors for the destination. Jean-Claude Killy even licensed his name to the ski resorts of Tignes and Val d'lsère under the name of "Espace Killy". Currently, most of the national ski competitor are sponsored by a local destination that requires the athletes to wear their resort's logo.

If the image of celebrities was a good communication vector when communications channels were mainly conceived as a one-to-many, since 2004 , the Web 2.0 revolution has offered new opportunities for communication that we can qualify as many-to-many. The number of authors rapidly surpassed the number of readers. This bulimia of willingness to share content quickly spread. This started with the explosion in the number of blogs, and now there are more than 1.4 billion 
Facebook users. Each of them has a substantial number of readers, even in absence of paid diffusion. This situation has created a new opportunity for marketers, who are now in a position to canalise this enormous amount of communication. The new challenge is to convince the social network repositories' authors or owners to talk about the brand or, in our case, the destination. This is because inhabitants are the ones who know best their destination. They are often in direct contact with tourists and know better than anybody else what they like, dislike or expect.

In the case of Savoie Mont Blanc, as mentioned above, with a job population of more than 49,000 persons working in the tourism industry, including 9,473 ski instructors, the destination has a precious number of authors with an enormous list of tourist contacts, who are ready to listen to their stories (Figure 3).

Therefore, the marketing department decided to create a network of "Ambassadeurs Savoie Mont Blanc" and started to recruit local leaders in 2016. They offered all citizens the opportunity to join this network to bring together a powerful and committed community serving the territory.

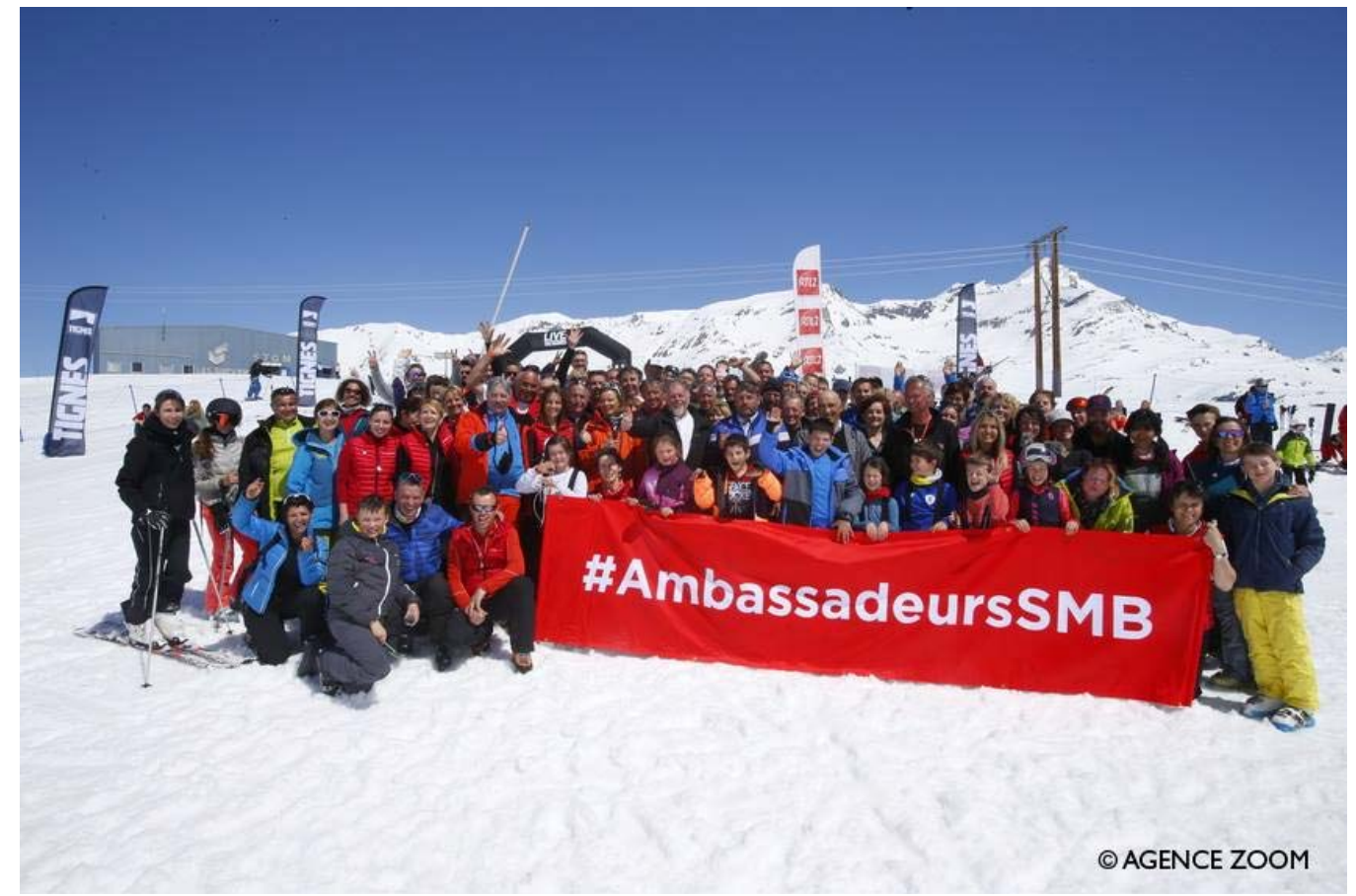

Figure 3. Savoie Mont-Blanc Tourism-Ambassadors welcoming customers on site Source:

https://www.facebook.com/savoiemontblanc.ambassadeurs/photos/a.226427421083392/599002263825904/?type $=3 \&$ theater

208 
Passionate about the territory (Savoie and Haute-Savoie), Savoyards of origin, adoption or heart, entrepreneurs, members of an association, artists, creators, students, sportsmen, visitors... everyone can join the network of Ambassadors Savoie Mont-Blanc.

Anyone in their field can enhance the territory with their knowledge and relationships create new opportunities for collective and individual success through exchanges and meetings within the network of Ambassadors Savoie Mont Blanc.

In exchange for their contributions, ambassadors get some non-financial advantages such as:

- Participating in meetings organized by the network of Ambassadors (around a theme, an event, a news item, a personality ...).

- Connecting with other members to expand their network.

- Receiving news from the Ambassadors and the territory.

- Showing their membership, by signing the Ambassadors Savoie Mont Blanc signature in their emails.

- Using the tools made available by the network (videos, logos, banners, presentations of the assets of the territory ...) for their actions.

- Being invited to events that contribute to the influence of the territory.

The DMO is currently maintaining two Facebook pages: one targeted to the potential tourists and another targeted to the Ambassadors (see Figure 4), However, in this stud, we only analyzed the Ambassadors Facebook page. 


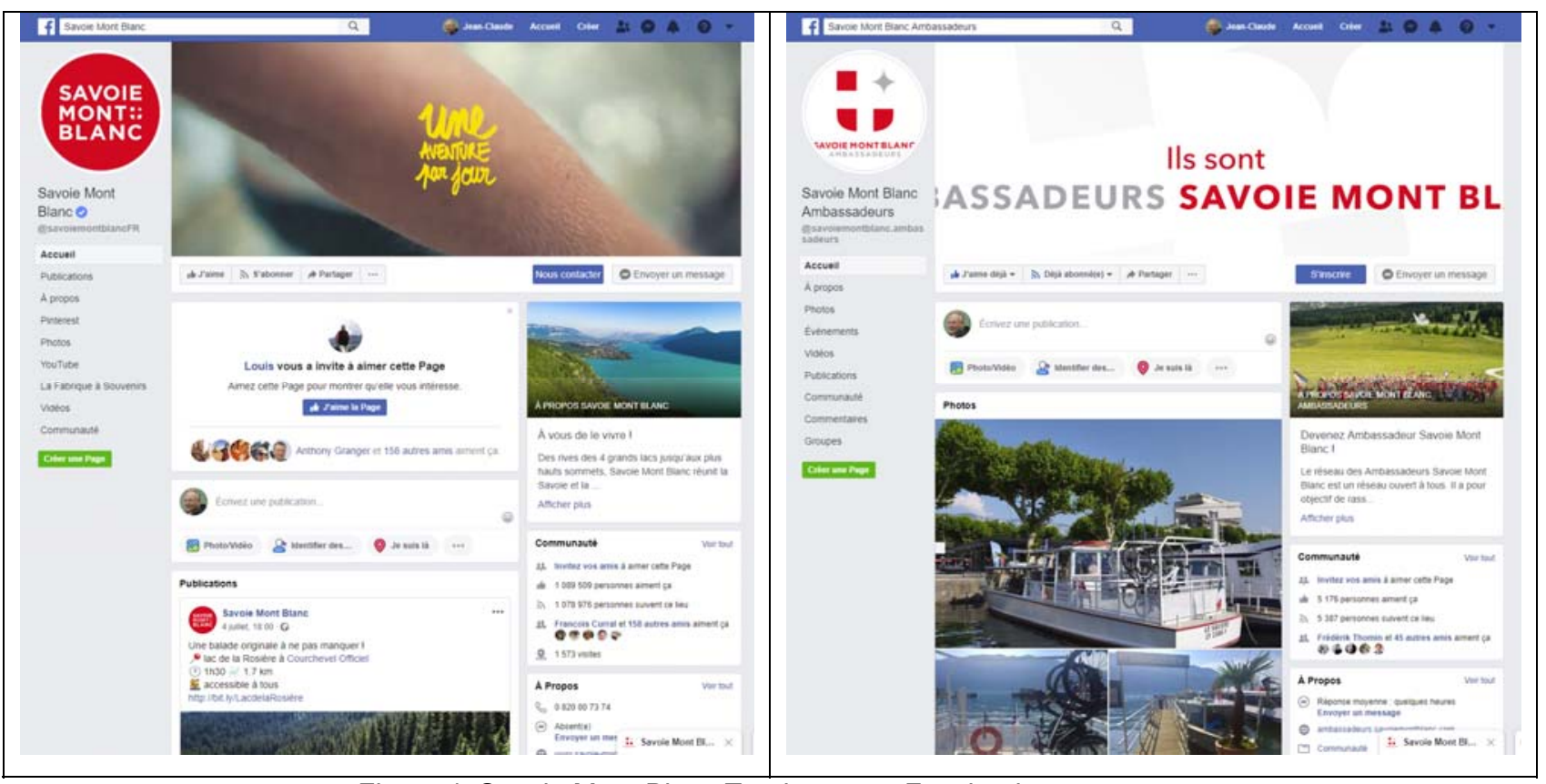

Figure 4. Savoie Mont-Blanc Tourism two - Facebook pages

Source:

https://www.facebook.com/savoiemontblanc.ambassadeurs/photos/a.226427421083392/599002263825904/?type $=3 \&$ theater

\section{1) SAMPLE AND METHODOLOGY}

The present investigation uses a qualitative research method. Denzin and Lincoln (2002) have argued that qualitative research has evolved and provides greater reflection that improves research process reliability; therefore, this methodology is fully accepted (Hosking \& McNamee 2007). To be more precise, content analysis is "a research technique for the objective and systematic description of the clear content of communication" (Berelson, 1952, p. 18). For Holsti (1969, p. 5) "content analysis is a research technique to formulate inferences identifying in a systematic and objective way specific characteristics within a text".

Qualitative content analysis is one of several methods currently available for data analysis and interpretation of its meaning (Schreier, 2012). It has been used for decades as a technique that analyses communication messages in focus (McMillan, 2000). According to Powers et al. (2010), it is a general term for a series of different strategies used to analyse text or "a method to identify, analyse and inform patterns (subjects) within data" (Braun \& Clarke, 2006, p. 79). Content analysis is a systematic, objective and quantitative method for studying communication messages 
and developing inferences about the relationship between messages and their environment (Krippendorff, 2012). It is a research method that follows a systematic and objective procedure to describe and quantify the phenomena (Schreier, 2012). It is a systematic approach to coding and classification, used to explore large amounts of textual information discretely to determine the trends and patterns of words used, their frequency, their relationships and the structures and discourses of communication (Grbich, 2007).

The value of a qualitative description lies not only in the knowledge that can originate from it but also in that it is a vehicle to present and treat meanings and solid findings (Holloway, 2005; Sandelowski, 2010). Some authors even consider content analysis as a type of narrative analysis (Sparkes, 2005).

Social networks can play several roles within the tourism sector, including the following: becoming communication channels for companies and organisations, offering and exchanging information; promoting and selling products and services (Law \& Lau, 2005; Pantano et al., 2011; Tse, 2003); enhancing the functionalities of traditional travel agencies and tour operators (Ye et al., 2011); sharing knowledge (Cheng, 2010); and generating new connections between users, customers and companies (Boyd \& Ellison, 2007). All this means that communication through social networks can generate positive and negative effects on tourists' opinions and consequently on their decisions (Knights et al., 2007; Pantano et al., 2011). Social networks possess powerful tools, such as interactivity, high quality and visualisation as well as fast search and transmission of information, and they can become one of the main tools for choosing tourist destinations (Hogg, 2010; Kim et al., 2010; Kwon \& Wen, 2010).

In this study, Facebook was the data collection source because Facebook generates the most referral traffic as mentioned by Martínez-Valerio (2012); for example, in the period between January and July 2019, Facebook generated an average of 924 million referrals per month and Twitter, the second-largest Web 2.0 platform, generated 97 million referrals each month (Arendt, 2019). Therefore, the analysis focused on the main social network for the Ambassadeurs Savoie Mont Blanc, namely their Facebook pages, which are a public social network. The period 
of analysis was in 2020 from May 24 until June 22 for two months. Three variables of analysis have been used: (1) fans, (2) content and (3) engagement.

For the item "fans" (1), the total number of fans was measured, and it increased during the analysis period. As for the variable "content" (2), the analysis was operationalised through the number of page posts with post types, the number of fan posts, the page post sources and the top 5 posts with more interaction. The last variable selected, "engagement" (3), was measured by most engaging post types.

The software used for data analysis was "Socialbakers" available via subscription at https://suite.socialbakers.com.

\section{RESULTS}

\section{1) FACEBOOK CONTENT RESULTS}

The graph in Figure 5 summarises the number of page posts with post types aggregated by day in the period of analysis. The activity of the Facebook pages was relatively high, with an average of 30 page posts a day (0.30) (see Figure 5). 


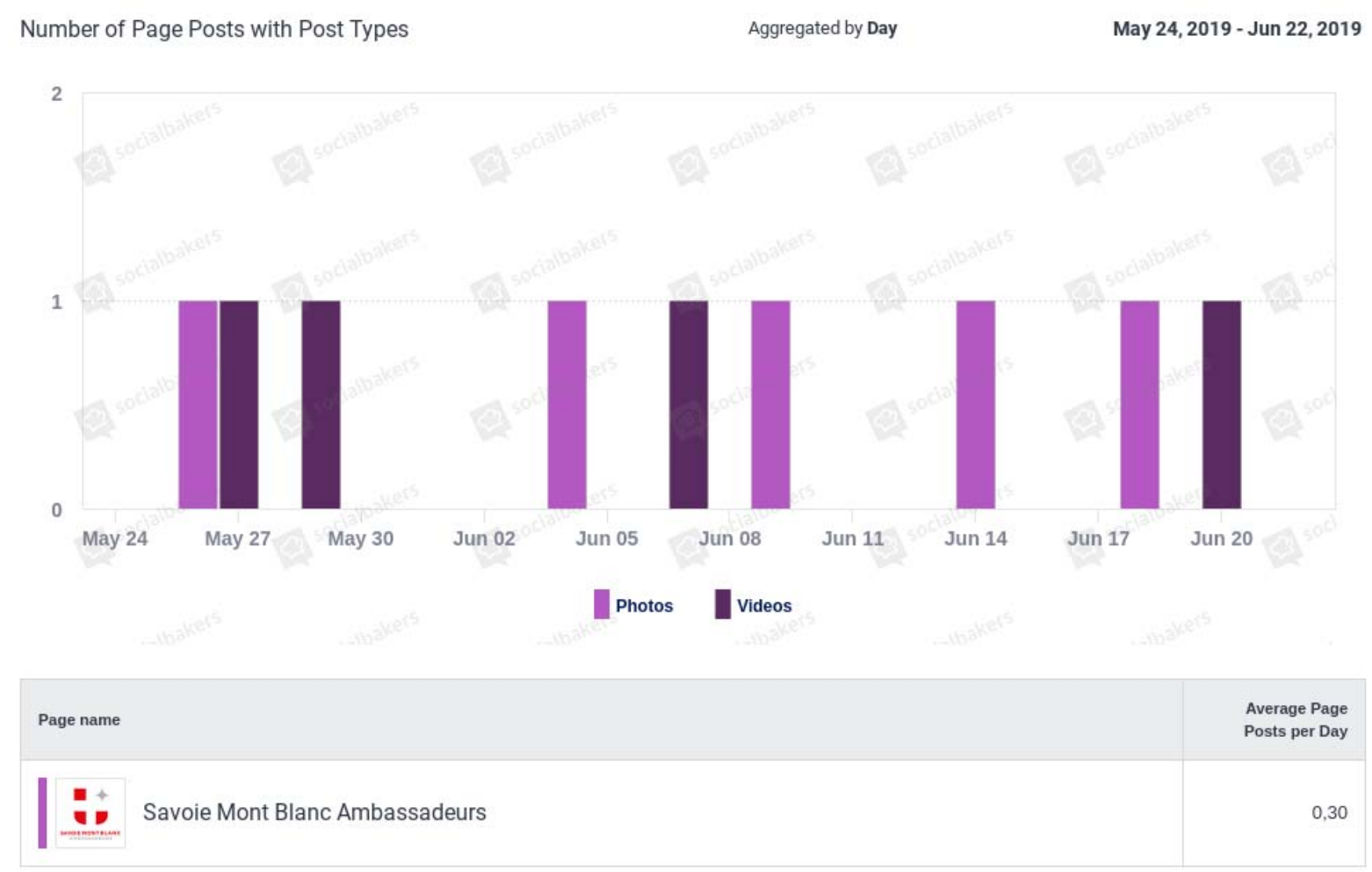

Figure 5. Savoie Mont Blanc Page Posts with Post Types

Facebook's most attractive contents are photos and videos, and both were posted regularly, 9 times in 28 days, with the preference being for photos ( 5 times). This kind of audiovisual support represents high engagement probabilities in taking advantage of this web tool.

The activity ratio of the top 5 posts shows the highest engagement in comments and shares, as can be seen in Figures 6, 7, 8, 9 and 10. 
$\square$ Les $\square$ de Chambëry Savoie Mont Blanc Handball vainqueurs de la Coupe de France ce week-end à Paris ! Des compétiteurs et un staff au top niveau. $\mathrm{\square}$ पा

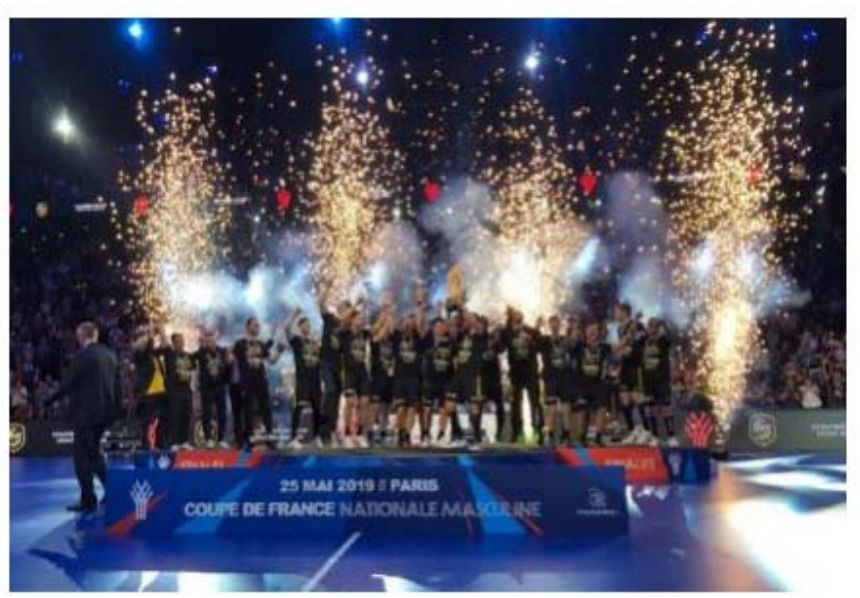

Interactions

197

Interactions

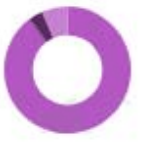

Comments

7

Shares

Total Interactions

Figure 6. Savoie Mont Blanc first Top 5-page post

From the results, it is clear that the first top 5-page post, retrieved on June 18, had a total of 197 interactions, including 154 likes that represent $3.83 \%$ of the targeted audience (the ambassadors). This percentage could certainly be improved if the communication strategy were properly explained to the 5,139 ambassadors.

\Découvrir le massif du Mont-Blanc en hélicoptère, juste magique :) ! Merci à notre Ambassadeur Jérémy Alpes Hélicoptères.

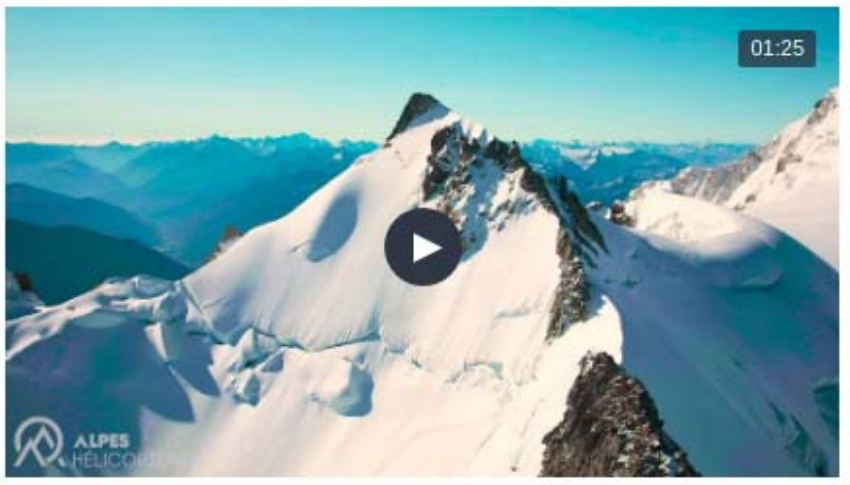

Video Length: $1 \mathrm{~min} 25 \mathrm{~s}$

\begin{tabular}{l|l} 
Interactions & Interactions per $1 \mathrm{k}$ \\
148 & Fans \\
& $\mathrm{N} / \mathrm{A}$
\end{tabular}

Interactions

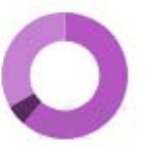

\begin{tabular}{lr}
\hline Comments & 8 \\
\hline Shares & 49 \\
\hline Total Interactions & 148
\end{tabular}

Figure 7. Savoie Mont Blanc second Top 5-page post 
A more detailed analysis showed that Savoie Mont Blanc's second top 5 page post also performed well with 148 interactions also on June 18. This Facebook page stands out with respect to the response item, as it presents 79 likes, 11 loves and one wow. Comments were also $100 \%$ positive, and the engagement rate was $33 \%$ (49 shares).

\section{Le $\mathrm{C}$ en Savoie Mont Blanc c'est : \\ $\square 5634 \mathrm{~km}$ itinéraires cyclo balisés \\ $\square 300 \mathrm{~km}$ de véloroutes et voies vertes \\ $\square 2885 \mathrm{~km}$ itinéraires des sites VTT FFC \\ Mais aussi de nombreuses manifestations cyclo $\square$ \\ http://bit.ly/Evénements-Cyclo}

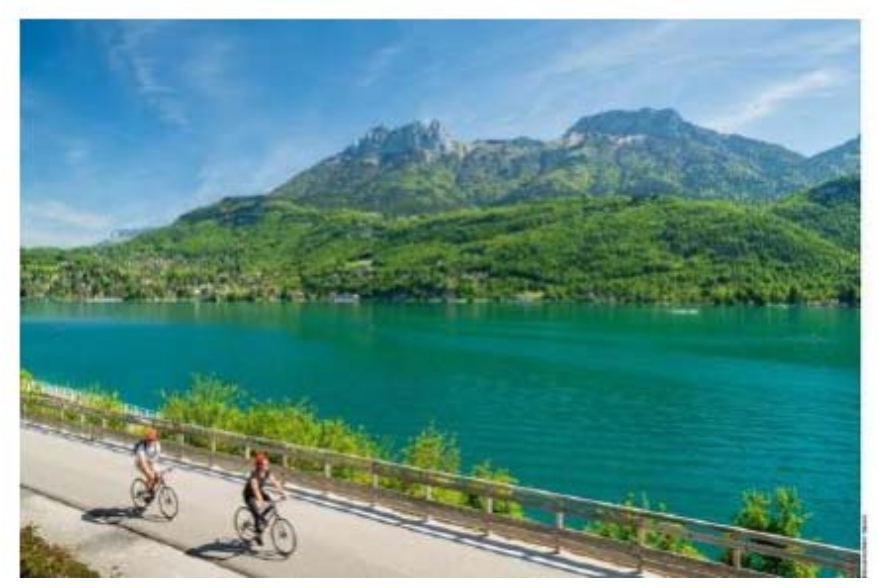

Figure 8. Savoie Mont Blanc third Top 5-page post

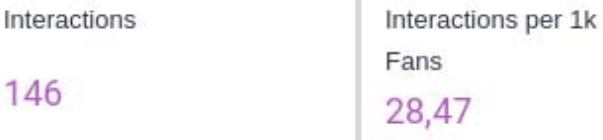

Interactions

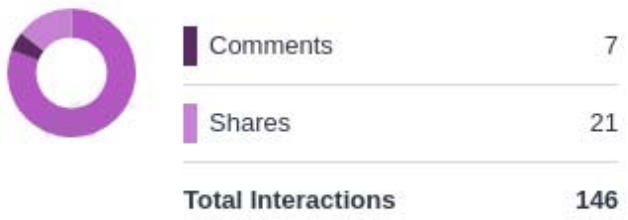

In line with previous results, the third top 5 page posted on June 18 had 146 interactions with 101 likes, 15 loves and two wows. A similar conclusion was reached when referring to comments; they were $100 \%$ positive in all seven reviews. The number of shares amounted to 21 . The posts told narratives through the images of the posted photos and videos, evidenced by the loves and wows. Thus, the images formed contain visual and cultural information that strengthen the brand and also bring recognition of the local culture (Camprubí \& Planas, 2020; Kislali et al. 2019; Woosnam et al., 2020). 
Très beau témoignage d'un passionné du territoire et Ambassadeur

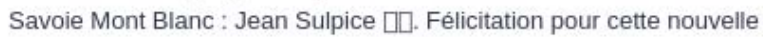
distinction "chevalier de l'ordre national du mérite", reçue il y a quelques jours $\mathrm{\square D}$

Vous aussi rejoignez la communauté $\mathrm{Bप}$

http://ambassadeurs.savoie-mont-blanc.com/

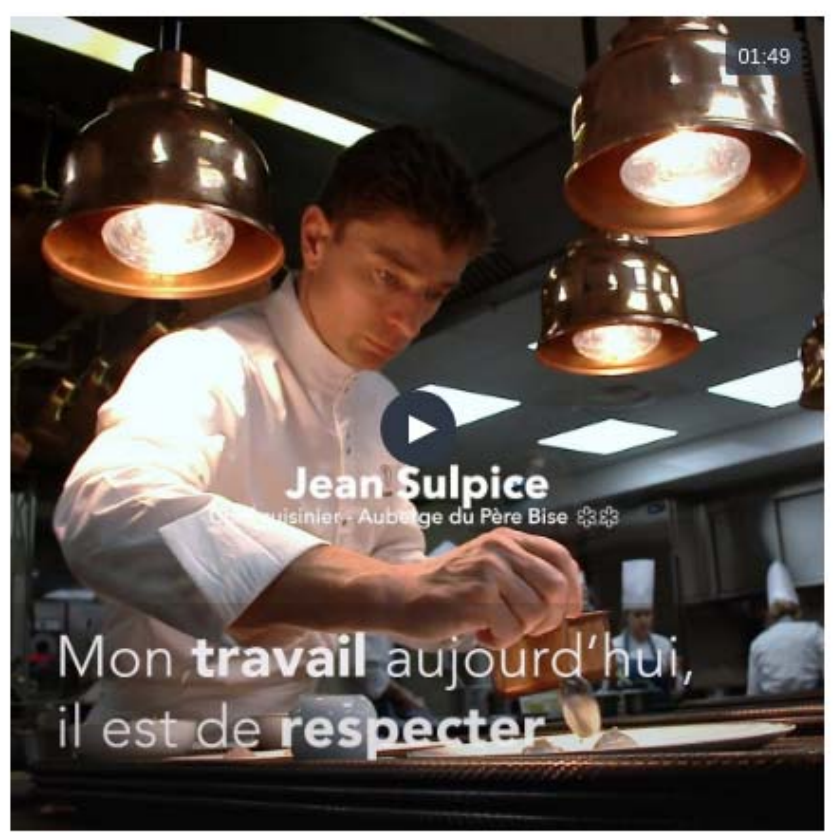

Video Length: $1 \mathrm{~min} 49 \mathrm{~s}$

\begin{tabular}{l||l} 
Interactions & Interactions per $1 \mathrm{k}$ \\
146 & Fans \\
& N/A
\end{tabular}

Interactions

\begin{tabular}{lr} 
M Comments & 1 \\
\hline Shares & 40 \\
\hline Total Interactions & $\mathbf{1 4 6}$
\end{tabular}

Figure 9. Savoie Mont Blanc fourth Top 5-page post

The Savoie Mont Blanc fourth top 5 page post is consistent with what has been found in the aforementioned. The page registered 146 interactions on June 18 and received 86 likes, 16 loves and three wows. It had 1005 positive comments and succeeded in getting 40 shares. 
\ Savez-vous qui est à la tête de l'incontournable Brasserie Du MontBlanc? Notre Ambassadeur Sylvain Chiron, un homme pétillant et fier de son territoire $\square$

Comme lui, rejoignez la communauté !

口 https://ambassadeurs.savoie-mont-blanc.com/

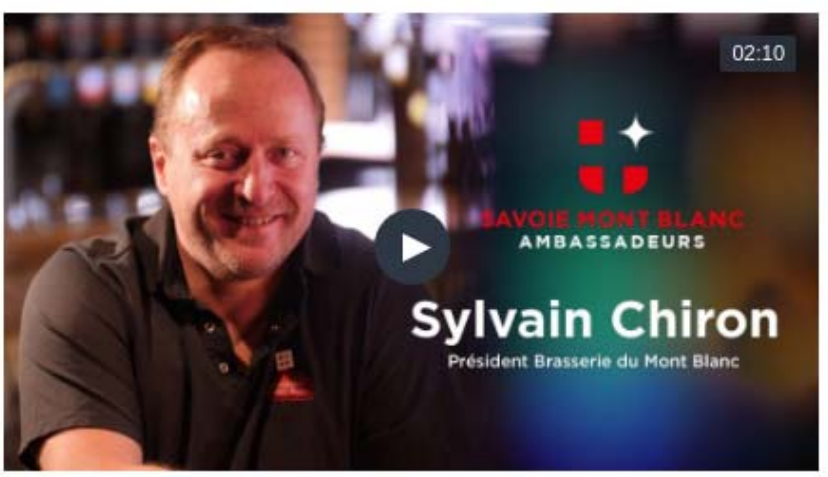

Video Length: 2 min $10 \mathrm{~s}$

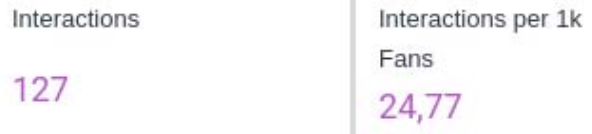

Interactions

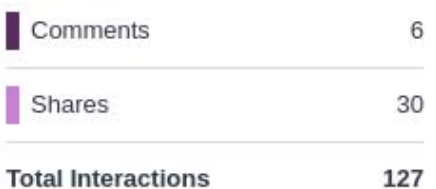

The last Savoie Mont Blanc top 5-page post, ranked by the number of post interactions, got 146 views on June 23, with 86 likes and five loves. Like all the others, the response in the comments was $100 \%$ positive.

The day with the greatest activity for the post in Figure 4 was Sunday, 23 June at 12:11h (126 interactions with 91 reactions, 5 comments and 30 shares).

\section{2) ENGAGEMENT RESULTS:}

A similar pattern of results was obtained when analysing the most engaging post types, namely video and photos. The analysis revealed an average of 124 interactions per post displaying a video; against 110 average interactions per post with uploaded photos (Figure 11). The high number of daily posts reveals destination associations and creates affective ties with the destination (Keller, 1993). At the same time, a dependent relationship emerges between organic image and induced image (Cardoso et al., 2018), which may be strategic in this relationship. 


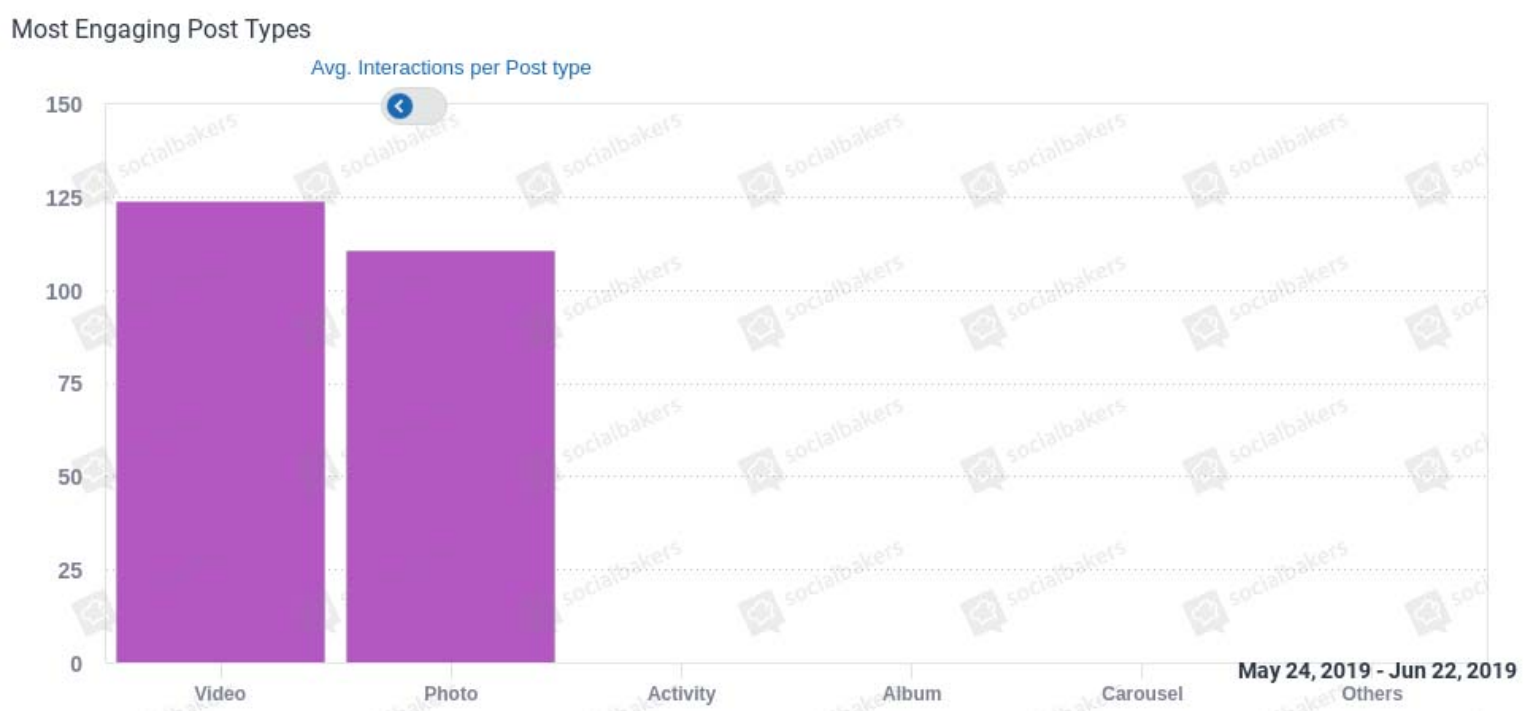

Summary of Most Engaging Post Types per Post Type

\begin{tabular}{|c|c|c|c|c|}
\hline Post Type & ${ }_{\downarrow}$ Distribution & Reactions & Comments & Shares \\
\hline 1. Video & $52,85 \%$ & $\begin{array}{r}352 \\
71,11 \%\end{array}$ & $\begin{array}{r}16 \\
3,23 \%\end{array}$ & $\begin{array}{r}127 \\
25,66 \%\end{array}$ \\
\hline 2. Photo & $47,15 \%$ & $\begin{array}{r}482 \\
87.32 \%\end{array}$ & $\begin{array}{r}14 \\
2.54 \%\end{array}$ & $\begin{array}{r}56 \\
10,14 \%\end{array}$ \\
\hline
\end{tabular}

Figure 11. Savoie Mont Blanc most engaging post types

Posting on the Facebook page regularly is an activity that can change daily in response to certain events or news that call for more attention. A piece of content can spread and go viral online, meaning that content is shared exponentially on the internet. Those are rare occasions, and content creation shows some consistency, as is the case of Savoie Mont Blanc Tourism Ambassadors' Facebook pages. Table 2 shows some patterns of variance according to the day of the week. On Sundays (197 interactions) the activity is higher and decreases as the week progresses (146 interactions), with Fridays being the lowest interaction day of the week.

\begin{tabular}{|l|c|}
\hline & Average interaction per post \\
\hline Sunday May, 26 & 167 \\
\hline Wednesday May, 29 & 148 \\
\hline Friday June, 7 & 146 \\
\hline Friday June 14 & 146 \\
\hline
\end{tabular}

Table 2. Savoie Mont-Blanc FB Ambassadors average number of interactions per post 
These data should be compared with the score obtained by the official Savoie Mont Blanc Tourism page https://www.facebook.com/savoiemontblancFR/ during the same period (Table 3):

\begin{tabular}{|c|c|c|c|c|c|}
\hline $\begin{array}{l}\text { Date of } \\
\text { the post }\end{array}$ & Subject & Likes & Comments & Share & $\begin{array}{c}\sum \text { of } \\
\text { interactions }\end{array}$ \\
\hline June 17 & $\begin{array}{l}\text { Montée des } \\
\text { alpages }\end{array}$ & 34000 & 2400 & 12000 & 48400 \\
\hline June 19 & $\begin{array}{l}\text { Ressentez le } \\
\text { calme }\end{array}$ & 6000 & 346 & 1200 & 7546 \\
\hline June 21 & Lac de Darbon & 9200 & 540 & 2000 & 11740 \\
\hline June 25 & $\begin{array}{l}\text { Brumisateurs } \\
\text { naturels }\end{array}$ & 11000 & 1000 & 6100 & 18100 \\
\hline & $\begin{array}{l}\text { Total for the } \\
\text { period }\end{array}$ & 60200 & 4286 & 21300 & 85786 \\
\hline
\end{tabular}

Table 3. Interactions with the Savoie Mont-Blanc FB official page

\section{CONCLUSIONS}

With 5,139 followers, the Facebook page of the Savoie Mont Blanc Ambassadeurs is a long way from reaching the official Facebook page of the Savoie Mont Blanc tourism destination with 1,079,052 followers on July 5, 2019. However, these pages have different roles. The one for the ambassadors is one of the tools used to animate the network of ambassadors. But with less than 200 interactions per post and two posts per week (0.3 per day), the DMO does not reach its communication goal that we initially estimated of 44,080 potential interactions per week according to our hypothesis. This scenario also reveals that it may be an intentional strategy to distinguish both Facebook profiles by keeping only one of the pages in the "official" position.

To improve engagement with users, several actions should be considered.

It should be clearly stated to the three subgroups of ambassadors that they are invited to share, like or/and comment on the posts published. The communication strategy should be articulated more clearly, as only $3.83 \%$ of the ambassador community currently react. 
In addition, it is necessary to increase the frequency of content generation when seeking to attract more attention and generate interest (which would also demand time on the part of the destination ambassadors). Interaction is not excessively high, with an average of 52 interactions for the five most successful posts, which translates to a reaction from $2.9 \%$ of followers. However, the engagement can be described as good at close to $50 \%$ in terms of photographs and even higher in the case of videos. This percentage confirms that research on Facebook's algorithm prefers posts with photos or videos over text-only posts. This allows the conclusion that the model is certainly correct in applying the concept of the long tail in extending the communication intermediaries by using citizens, but the implementation needs to be revisited to approach the performance of the public Facebook page so that advantage can be taken of the dynamics of Facebook's algorithm.

Finally, the present research also has some shortcomings. The analysis focused on only one period of time and only on the social media platform Facebook. Further research should establish whether this trend is significant and confirm these initial findings by extending the period of analysis to one year. It should also apply the study to the Facebook pages of the ambassadors who are the most active. Facebook is not the only social network used by tourists, so Pinterest, Instagram or Linkedln should also be explored. Moreover, communication is exclusively done in French, while the destination welcomes a large number of foreigners. Therefore, impacts on social networks in other languages may be a source of interesting findings.

This study also highlights the projected destination image of Savoie Mont Blanc as a tourism destination, the induced image of the ambassadors and the official tourism promoter, but it does not take into account the consumer side and the perceived image by tourists. In this context, further studies may extend the analysis to tourists' comments and compare the induced versus perceived image. Last but not least, it is also be recommended to conduct a cost-efficiency study approach comparing the cost of "hiring" a well-known celebrity versus the cost of animation activities for tourism ambassadors' associations.

\section{Acknowledgements}


This research is financed by national funds through FCT - Foundation for Science and Technology, I.P., within the scope of the UIDB / 04470/2020 project.

\section{References}

Aaker, D.A. Measuring brand equity across products and markets. California Management Review, Vol. 38, No 3, 1996, pp. 102-120.

Alonso, A.D.; Krajsic, V. Food heritage down under: olive growers as Mediterranean 'food ambassadors'. Journal of Heritage Tourism, Vol. 8, No 2-3, 2013, pp. 158-171.

Andersson, M.; Ekman, P. Ambassador networks and place branding. Journal of Place Management and Development, Vol. 2, No 1, 2009, pp. 41-51.

Arendt, K. (August 22th, 2019). Outsized influence: the size of social media platforms has little to do with their referral traffic. Retrieved from https://blog.parse.ly/post/8921/outsized-influence-the-size-of-social-media-platformshas-little-to-do-with-their-referral-trafficl [accessed 23 March 2021].

Babbie, E.R.; Huitt, R.E. Practising Social Research: Guided Activities to Accompany the Practice of Social Research. Belmont, CA: Wadsworth Publishing, 1979.

Baloglu, S.; Mangaloglu, M. Tourism destination images of Turkey, Egypt, Greece, and Italy as perceived by US-based tour operators and travel agents. Tourism Management, Vol. 22, No 1, 2001, pp. 1-9.

Baloglu, S.; McCleary, K.W. A model of destination image formation. Annals of Tourism Research, Vol. 26, No 4, 1999, pp. 868-897.

Battour, M.; Ismail, M.N.; Battor, M. The impact of destination attributes on Muslim tourist's choice. International Journal of Tourism Research, Vol. 13, No 6, 2011, pp. 527-540.

Beerli, A.; Martin, J.D. Factors influencing destination image. Annals of Tourism Research, Vol. 31, No 3, 2004, pp. 657-681. 
Berelson, B. Content analysis in communication research. Glencoe, III: Free Press, 1952.

Bergkvist, L.; Hjalmarson, H.; Mägi, A.W. A new model of how celebrity endorsements work: attitude toward the endorsement as a mediator of celebrity source and endorsement effects. International Journal of Advertising, Vol. 35, No 2, 2016, pp. 171-184.

Bergkvist, L.; Zhou, K.Q. Celebrity endorsements: a literature review and research agenda. International Journal of Advertising, Vol. 35, No 4, 2016, pp. 642-663.

Blain, C.; Levy, S.E.; Ritchie, J.B. Destination branding: Insights and practices from destination management organizations. Journal of Travel Research, Vol. 43, No 4, 2005, pp. 328-338.

Boo, S.; Busser, J.; Baloglu, S. A model of customer-based brand equity and its application to multiple destinations. Tourism Management, Vol. 30, No 2, 2009, pp. 219-231.

Boyd, D.; Ellison, N.B. (2007). Social Network Sites: Definition, History and Scholarship. Journal of Computer-Mediated Communication, Vol. 13, No 1, 2007, pp. 210-230.

Braun, V.; Clarke, V. Using thematic analysis in psychology. Qualitative Research in Psychology, Vol. 3, No 2, 2006, pp. 77-101.

Cai, L.A. Cooperative branding for rural destinations. Annals of Tourism Research, Vol. 29, No 3, 2002, pp. 720-742.

Camprubí, R.; Planas, C. El storytelling en la marca de destinos turísticos: el caso de Girona. Cuadernos de Turismo, No 46, 2020, pp. 269-289.

Cardoso, L.; Dias, F.; Araujo, A.; Marques, I. A destination imagery processing model: Structural differences between dream and favourite destinations. Annals of Tourism Research, Vol. 74, No. 1, 2019, pp. 81-94. 
Cardoso, L.; Estevão, C.; Fernandes, C.; Alves, H. Film-Induced Tourism: A Systematic Literature Review. Tourism \& Management Studies, Vol. 13, No 3, 2018, pp. 23-30.

Cha, M.; Haddadi, H.; Benevenuto, F.; Gummadi, K.P. Measuring user influence in twitter: The million follower fallacy. Proceedings of the Fourth International AAAI Conference on Weblogs and Social Media (ICWSM), 2010, pp. 10-17.

Cheng, H.L. Seeking knowledge or gaining legitimacy? Role of social networks on new practice adoption by OEM suppliers. Journal of Business Research, Vol. 63 No 8, 2010, pp. 824-831.

Chung, S.; Cho, H. Fostering parasocial relationships with celebrities on social media: Implications for celebrity endorsement. Psychology \& Marketing, Vol. 34, No 4, 2017, pp. 481-495.

Crompton, J.L. Motivations for pleasure vacation. Annals of Tourism Research, Vol. 6, No 4, 1979, pp. 408-424.

De Veirman, M.; Cauberghe, V.; Hudders, L. Marketing through Instagram influencers: The impact of number of followers and product divergence on brand attitude. International Journal of Advertising, Vol. 36, No 5, 2017, pp. 798-828.

Denzin, N.K.; Lincoln, Y.S. The qualitative inquiry reader. Thousand Oaks, Calif.: Sage, 2002.

Dias, F.; Cardoso, L. How can brand equity for tourism destinations be used to preview tourists' destination choice? An overview from the top of Tower of Babel. Tourism \& Management Studies, Vol. 13, No 2, 2018, pp. 13-23.

Diesbach, P.B. Touristic destination ambassadors, case analysis and conceptualization. How to better understand and use brand ambassadors in cognitive, affective and experiential approaches. Tourism and Hospitality Management, Vol. 18, No 2, 2012, pp. 229-258. 
Echtner, C.M.; Ritchie, J.R. The meaning and measurement of destination image. Journal of Tourism Studies, Vol. 14, No. 1, 2003, pp. 37-48.

Ekinci, Y. An investigation of the determinants of customer satisfaction. Tourism Analysis, Vol. 8, No 2, 2003, pp. 193-196.

Gallarza, M.G.; Saura, I.G.; García, H.C. Destination image: Towards a conceptual framework. Annals of Tourism Research, Vol. 29, No 1, 2002, pp. 56-78.

García, J.A.; Gómez, M.; Molina, A. A destination-branding model: An empirical analysis based on stakeholders. Tourism Management, Vol. 33, No 3, 2012, pp. 646661.

Gartner, W.C. Image formation process. In Uysal, M.; Fesenmaier, D. (eds). Communication and Channel Systems in Tourism Marketing. New York: Haworth Press, 1993, pp. 191-215.

Gartner, W.C. Image formation process. Journal of Travel \& Tourism Marketing, Vol. 2, No 2-3, 1994, pp. 191-216.

Gartner, W.C.; Ruzzier, M.K. Tourism destination brand equity dimensions: Renewal versus repeat market. Journal of Travel Research, Vol. 50, No 5, 2011, pp. 471-481.

Glover, P. Celebrity endorsement in tourism advertising: Effects on destination image. Journal of Hospitality and Tourism Management, Vol. 16, No 1, 2009, pp. 1623.

Govers, R., Go; F.M.; Kumar, K. Promoting tourism destination image. Journal of Travel Research, Vol. 46, No 1, 2007, pp. 15-23.

Grbich, C. An introduction: Qualitative data analysis. London, UK: Sage, 2007.

Gunn, H.M. Histochemical observations on laryngeal skeletal muscle fibres in 'normal' horses. Equine Veterinary Journal, Vol. 4, No 3, 1972, pp. 144-148. 
Hallmann, K.; Zehrer, A.; Müller, S. Perceived destination image: An image model for a winter sports destination and its effect on intention to revisit. Journal of Travel Research, Vol. 54, No 1, 2015, pp. 94-106.

Hankinson, G. The brand images of tourism destinations: a study of the saliency of organic images. Journal of Product \& Brand Management, Vol. 13, No 1, 2004, pp. 614.

Hankinson, G. The measurement of brand orientation, its performance impact, and the role of leadership in the context of destination branding: An exploratory study. Journal of Marketing Management, Vol. 28, No 7-8, 2012, pp. 974-999.

Harfst, J., Pichler, P.; Fischer, W. Regional Ambassadors-An Innovative Element for the Development of Rural Areas? European Countryside, Vol. 9, No 2, 2017, pp. 359-374.

Hogg, T. Inferring preference correlations from social networks. Electronic Commerce Research and Applications, Vol. 9, No 1, 2010, pp. 29-37.

Hollensen, S.; Schimmelpfennig, C. Selection of celebrity endorsers: A case approach to developing an endorser selection process model. Marketing Intelligence \& Planning, Vol. 31, No 1, 2013, pp. 88-102.

Holloway, I. (ed). Qualitative research in health care. Berkshire, UK: McGraw-Hill Education, 2005.

Holsti, O.R. Content analysis for the social sciences and humanities. Reading. MA: Addison-Wesley, 1969.

Hosany, S.; Ekinci, Y.; Uysal, M. Destination image and destination personality. International Journal of Culture, Tourism and Hospitality Research, Vol. 1, No 1, 2007, pp. 62-81.

Hosking, D.M.; McNamee, S. Back to basics: Appreciating appreciative inquiry as not 'normal' science. Al Practitioner, Vol. 11, No November, 2007, pp. 12-16. 
Jabreel, M.; Moreno, A.; Huertas, A. Semantic comparison of the emotional values communicated by destinations and tourists on social media. Journal of Destination Marketing \& Management, Vol. 6, No 3, 2017, pp. 170-183.

Keller, K.L. Administración estratégica de marca branding. México: Pearson Educación, 2008.

Keller, K.L. Conceptualizing, measuring, and managing customer-based brand equity. Journal of Marketing, Vol. 57, No 1, 1993, pp. 1-22.

Keller, K.L. Reflections on customer-based brand equity: Perspectives, progress, and priorities. AMS Review, Vol. 6, No 1, 2016, pp. 1-16.

Kim, H.; Richardson, S.L. Motion picture impacts on destination images. Annals of Tourism Research, Vol. 30, No 1, 2003, pp. 216-237.

Kim, H.; Stepchenkova, S. Effect of tourist photographs on attitudes towards destination: Manifest and latent content. Tourism Management, Vol. 49, No August, 2015, pp. 29-41.

Kim, W.; Jeong, O.R.; Lee, S.W. On social Web sites. Information systems, Vol. 35 No 2, 2010, pp. 215-236.

Kislali, H.; Kavaratzis, M.; Saren, M. Destination image formation: Towards a holistic approach. International Journal of Tourism Research, Vol. 22, No 2, 2020, pp. 266276.

Knights, D.; Willmott, H.; Brewis, J. Introducing organizational behaviour and management. London: Thomson, 2007.

Konecnik, M. Customer-based brand equity for tourism destination: Conceptual model and its empirical verification. Ljubljana: University of Ljubljana, 2005.

Konecnik, M.; Gartner, W.C. Customer-based brand equity for a destination. Annals of Tourism Research, Vol. 34, No 2, 2007, pp. 400-421. 
Krippendorff, K. Content analysis: An introduction to its methodology. Thousand Oaks, Calif.: Sage Publications, 2012.

Kwon, O.; Wen, Y. An empirical study of the factors affecting social network service use. Computers in human behavior, Vol. 26, No 2, 2010, pp. 254-263.

Law, R.; Lau, W. A study of the perceptions of Hong Kong hotel managers on the potential disintermediation of travel agencies. Journal of Travel \& Tourism Marketing, Vol 17, No 2-3, 2005, pp. 117-131.

Majid, G.M. (2019). A Study on 'Tourism Ambassadors' in Indonesia Content Analysis, Instagram Accounts, and Tourism Promotion Strategy. In 5th International Conference on Information Management (ICIM), IEEE, pp. 317-326.

Martínez-Valerio, L. Estrategias de promoción turística a través de Facebook. Palabra Clave, Vol. 15 No 2, 2012, pp. 318-338.

McCracken, G. Who is the celebrity endorser? Cultural foundations of the endorsement process. Journal of consumer research, Vol. 16, No 3, 1989, pp. 310321.

McMillan, S.J. The microscope and the moving target: The challenge of applying content analysis to the World Wide Web. Journalism \& Mass Communication Quarterly, Vol. 77, No 1, 2000, pp. 80-98.

Min, K.H.; Lee, T.J. Customer satisfaction with Korean restaurants in Australia and their role as ambassadors for tourism marketing. Journal of Travel \& Tourism Marketing, Vol. 31, No 4, 2014, pp. 493-506.

Önder, I.; Marchiori, E. A comparison of pre-visit beliefs and projected visual images of destinations. Tourism Management Perspectives, Vol. 21, 2017, pp. 42-53.

Pan, X.; Rasouli, S.; Timmermans, H. Investigating tourist destination choice: Effect of destination image from social network members. Tourism Management, Vol. 83, No April, 2021, pp. 104217-. 
Pantano, E.; Servidio, R.; Viassone, M. An exploratory study of the tourist-computer interaction: the role of web site usability on hotel quality perception. International Journal of Digital Content Technology and its Applications, Vol. 5, No 5, 2011, pp. 208-216.

Pike, S. Destination brand positions of a competitive set of near-home destinations. Tourism Management, Vol. 30, No 6, 2009, pp. 857-866.

Pike, S.; Page, S.J. Destination Marketing Organizations and destination marketing: A narrative analysis of the literature. Tourism Management, Vol. 41, 2014, pp. 202227.

Powers, B.A.; Knapp, T.; Knapp, T.R. Dictionary of nursing theory and research. New York: Springer Publishing, 2010.

Prebensen, N.K. Exploring tourists' images of a distant destination. Tourism Management, Vol. 28, No 3, 2007, pp. 747-756.

Pretto, A. Different Landscape Perceptions of the Same Territorial Area: A Research Study in Italy. Space and Culture, Vol. 24 No 1, 2021, pp. 144-156.

Qu, H.; Kim, L.H.; Im, H.H. A model of destination branding: Integrating the concepts of the branding and destination image. Tourism Management, Vol. 32, No 3, 2011, pp. 465-476.

Rehmet, J.; Dinnie, K. Citizen brand ambassadors: Motivations and perceived effects. Journal of Destination Marketing \& Management, Vol. 2 No 1, 2013, pp. 3138.

Sandelowski, M. What's in a name? Qualitative description revisited. Research in Nursing \& Health, Vol. 33, No 1, 2010, pp. 77-84.

Schreier, M. Qualitative content analysis in practice. London: Sage Publications, 2012. 
Scott, N.; Cooper, C.; Baggio, R. Destination networks: four Australian cases. Annals of Tourism Research, Vol. 35, No 1, 2008, pp. 169-188.

Serna, A.; Kepa, J.; Alzua, A. Towards a better understanding of the cognitive destination image of Euskadi-Basque Country based on the analysis of UGC. In Xiang, Z.; Tussyadiah, L. (eds). Information and Communication Technologies, Cham: Springer, 2014, pp. 395-407.

Sparkes, A.C. Narrative analysis: exploring the whats and hows of personal stories. Qualitative Research in Health Care, Vol. 1, No 1, 2005, pp. 191-209.

Tse, A.C.B. Disintermediation of travel agents in the hotel industry. International Journal of Hospitality Management, Vol. 22, No 4, 2003, pp. 453-460.

Uchinaka, S.; Yoganathan, V.; Osburg, V.S. Classifying residents' roles as online place-ambassadors. Tourism Management, Vol. 71, No April, 2019, pp. 137-150.

Wood, N.T.; Muñoz, C.L. 'No rules, just right' or is it? The role of themed restaurants as cultural ambassadors. Tourism and Hospitality Research, Vol. 7, No 3-4, 2007, pp. 242-255.

Woosnam, K.M.; Stylidis, D.; Ivkov, M. Explaining conative destination image through cognitive and affective destination image and emotional solidarity with residents. Journal of Sustainable Tourism, Vol. 28, No 6, 2020, pp. 1-19.

Vaghela, P.S. A Study on Consumer Attitude Perception about Celebrity Endorsement. International Journal of Marketing and Technology, Vol. 2, No 12, 2012, pp. 150-163.

Xiong, Y.; Cheng, Z.; Liang, E.; Wu, Y. Accumulation mechanism of opinion leaders' social interaction ties in virtual communities: Empirical evidence from China. Computers in Human Behavior, Vol. 82, 2018, pp. 81-93.

Ye, Q.; Law, R.; Gu, B.; Chen, W. The influence of user-generated content on traveler behavior: An empirical investigation on the effects of e-word-of-mouth to 
hotel online bookings. Computers in Human behavior, Vol. 27, No 2, 2011, pp. 634639.

Yoganathan, V.; Osburg, V.S.; Akhtar, P. Sensory stimulation for sensible consumption: Multisensory marketing for e-tailing of ethical brands. Journal of Business Research, Vol. 96, No March, 2019, pp. 386-396.

Article info: Received 13/01/2021. Accepted 06/04/2021. Refereed anonymously. 